\title{
Living Healthy Together
}

National Cancer Institute

\section{Source}

National Cancer Institute. Living Healthy Together. NCI Thesaurus. Code C160752.

Intervention that focuses on delivering education and support to breast cancer survivors

and their partners across a range of topics including social support, sleep and fatigue, stress and stress management, nutrition, and physical activity. 